\title{
The an11 locus controlling flower pigmentation in petunia encodes a novel WD-repeat protein conserved in yeast, plants, and animals
}

\author{
Nick de Vetten, Francesca Quattrocchio, Joseph Mol, and Ronald Koes ${ }^{1}$ \\ Department of Genetics, Institute for Molecular Biological Sciences, Vrije Universiteit, BioCentrum Amsterdam, $1081 \mathrm{HV}$ \\ Amsterdam, The Netherlands
}

\begin{abstract}
In petunia flowers, the loci an1, an2, and an11 control the pigmentation of the flower by stimulating the transcription of anthocyanin biosynthetic genes. The an1 and an2 locus were recently cloned and encode a basic helix-loop-helix (bHLH) and MYB-domain transcriptional activator, respectively. Here, we report the isolation of the an11 locus by transposon tagging. RNA gel blot experiments show that an11 is expressed independently from an1 and an2 throughout plant development, as well as in tissues that do not express the anthocyanin pathway. It encodes a novel WD-repeat protein that is highly conserved even in species that do not produce anthocyanins such as yeast, nematodes, and mammals. The observation that the human an11 homolog partially complements the an11 petunia mutant in transient assays shows that sequence similarity reflects functional conservation. Overexpression of an2 in an11- petals restored the activity of a structural anthocyanin gene in transient assays, indicating that AN11 acts upstream of AN2. Cell fractionation experiments show that the bulk of the AN11 protein is localized in the cytoplasm. Taken together, this indicates that AN11 is a cytoplasmic component of a conserved signal transduction cascade that modulates AN2 function in petunia, thereby linking cellular signals with transcriptional activation.
\end{abstract}

[Key Words: signal transduction; anthocyanin; transcription control; MYB; WD-40; petunia]

Received January 29, 1997; revised version accepted April 9, 1997.

The flavonoid biosynthetic pathway in plants is branched and produces a variety of products with diverse biological functions. For instance, anthocyanin pigments in flowers are visual signals to pollinators, whereas flavonols protect the plant from UV light and are required for the development of pollen (for review, see Koes et al. 1994; Shirley 1996). Given these different functions, it is not surprising that the expression of the flavonoid biosynthetic genes, encoding enzymes of the pathway, is induced by a variety of factors. These factors include hormones and factors that determine tissue-specificity, as well as external signals such as light, temperature, and pathogens (for review, see Mol et al. 1996). The underlying regulatory mechanisms have been most intensively studied in relation to the biosynthesis of anthocyanin pigments, because they provide a convenient visible marker.

Some steps in the primary light signal transduction cascade have been elucidated. The tomato aurea mutant lacks active phytochrome and fails to synthesize anthocyanins. Anthocyanin synthesis can be restored by mi-

${ }^{1}$ Corresponding author.

E-MAIL koes@bio.vu.nl; FAX +31-20-4447155. croinjection of different signaling compounds. On the basis of results with antagonists of animal $G$ proteins (Neuhaus et al. 1993), it is suggested that phytochrome acts through heterotrimeric $G$ proteins. Downstream from the G proteins, cyclic GMP is most likely the signaling molecule leading to activation of anthocyanin synthesis (Bowler et al. 1994a,b).

The transcription factors that are involved in the terminal steps of the signal-transduction cascades have been studied by genetic strategies in maize, snapdragon, and petunia (for reviews, see Dooner et al. 1991; Mol et al. 1996). Analysis of anthocyanin mutants in maize has shown that transcription of all the structural anthocyanin biosynthetic genes is controlled by two gene families (Fig. 1A). Both families comprise multiple genes that encode functionally similar proteins with distinct spatial expression patterns (Ludwig and Wessler 1990; Cone et al. 1993; Consonni et al. 1993). $c 1$ and $p 1$ encode MYB domain proteins (Paz-Ares et al. 1987; Cone et al. 1993), while the $r / b$ gene family encodes proteins with a basic helix-loop-helix (bHLH) DNA-binding motif (Ludwig and Wessler 1990; Consonni et al. 1993). Recent studies indicate that the $c 1 / p l$ and $r / b$ regulators are highly conserved and interchangeable between plant species. Lloyd et al. (1992) showed that introduction of a maize $r$ gene 


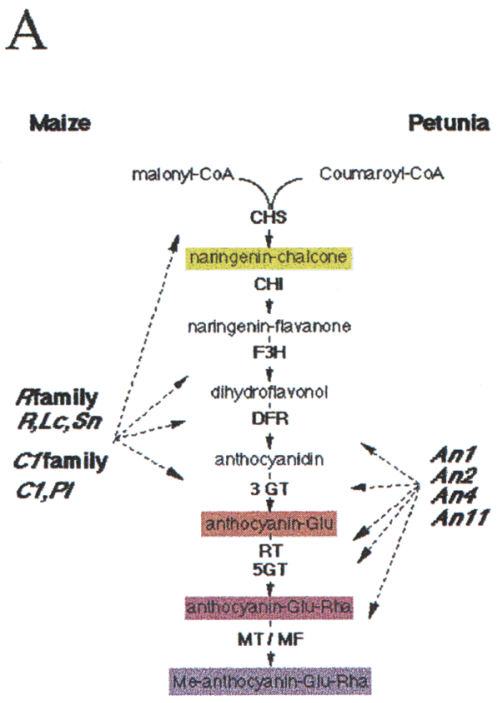

\section{$\mathrm{B}$}
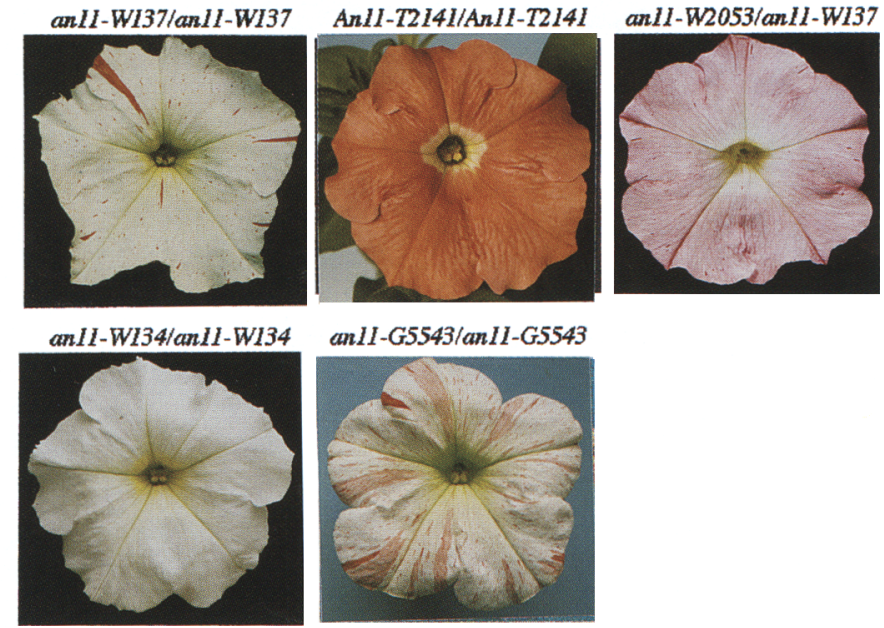

anII-G5543/anII-G5543

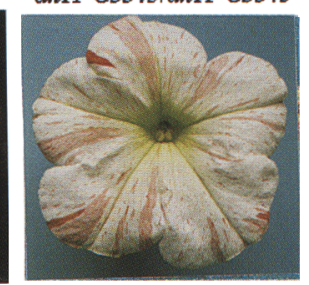

Figure 1. Genes involved in anthocyanin synthesis in maize and petunia and phenotypes of an11-mutants. $\{A \mid$ The anthocyanin biosynthesis pathway and its regulation in maize and petunia. Enzymes: $|\mathrm{CHS}|$ chalcone synthase; $(\mathrm{CHI})$ chalcone flavanone isomerase; $(\mathrm{F} 3 \mathrm{H})$ flavanone 3-hydroxylase; (DFR) dihydroflavonol 4-reductase; (3GT) UDP-glucose flavonoid glycosyltransferase; (RT) anthocyanin rhamnosyltransferase; $\{5 \mathrm{GT}\rangle$ UDP-glucose flavonoid 5-O-glycosyltransferase; $|\mathrm{MT} / \mathrm{MF}\rangle$ methyltransferase. Names of the regulatory loci controlling anthocyanin biosynthesis in maize (left $\mid$ or in petunia $\mid$ right $\mid$ are given in italics. Changes in color following modifications to the basic flavonoid ring structure are indicated. $|B|$ Flower pigmentation patterns specified by different $a n 11$ alleles. The genotypes are specified above each flower.

in Arabidopsis and tobacco enhanced anthocyanin production. In snapdragon, delila regulates anthocyanin biosynthesis in the tube of the flower and was found to encode an $r / b$ homolog (Goodrich et al. 1992). In petunia four loci, an1, an2, an4, and an11, control transcription of a subset of structural anthocyanin genes in the flower and mutations in these loci can be complemented by $c 1$ and an $r$ gene from maize (Quattrocchio et al. 1993; see also Fig. 1A). In addition, an1, an2, and an11 play a role in the control of intracellular $\mathrm{pH}$ in petal cells (Quattrocchio 1994|. Recently, an 1 and an 2 were cloned by transposon tagging and shown to encode a bHLH protein (C. Spelt, J. Mol, and R. Koes, unpubl.) and an MYB-type protein homologous to $\mathrm{cl} / \mathrm{pl}$, respectively (Quattrocchio 1994).

Little is known about the mechanisms that control these MYB and bHLH regulators and the modulation of their activity by upstream signal transduction cascades. One good candidate for transcriptional regulation of $c 1$ is the maize viviparous-1 (vp1) gene (McCarty et al. 1991). Mutations in the $v p 1$ gene have a pleiotropic effect on seed development, in that the gene is required for both seed dormancy and seed pigmentation. It was shown that $v p 1$ controls the anthocyanin pathway primarily through transcriptional regulation of the $c 1$ gene. The $r$ gene apparently does not require $v p 1$ expression (Hattori et al. 1992).

In this report, we present the molecular analysis of the anthocyanin regulatory gene an 11 . The an 11 gene encodes a novel protein containing five WD-repeats, a motif first noted in the $G$ protein $\beta$ subunit of the bovine retinal transducin (Fong et al. 1986). Because the AN11 protein is localized in the cytoplasm, it may regulate gene expression of the anthocyanin biosynthetic pathway through post-translational modification of the transcription factors, most likely the MYB domain protein AN2. The presence of AN1l protein homologs in mammals and yeast suggests an evolutionary conserved function in all eukaryotes.

\section{Results}

\section{Isolation of the anl l gene}

The unstable an11-W137 allele was isolated in the petunia line W138 (Doodeman et al. 1984). Homozygotes for this allele have white flowers with red and occasionally pink spots, presumably caused by the somatic excision of a transposable element (Fig. 1B). Among progeny obtained by selfing of an 11 mutable plants, we identified three full revertant alleles, two partial revertant, and four stable recessive alleles that originated from independent sporogenic excision events (Fig. 1B). Furthermore, a novel unstable allele, an11-G5543, was recovered. an11-G5543 flowers differ from an11-W137 flowers in that they contain a large number of pink spots whereas red spots are seen only occasionally (Fig. 1B). A sporogenic excision event from an11-G5543 yielded the partial revertant allele an11-Z2297.

All unstable alleles isolated in the W138 background that were analyzed so far contained insertions of the 300bp transposable element $d T p h 1$ (Gerats et al. 1990; Souer 
et al. 1996). Therefore, we anticipated the presence of $d T p h 1$ in the an11-W137 allele. To clone a fragment of the an11 locus, we isolated $d T p h 1$ flanking sequences unique for an an11-W137 plant by combining inverse PCR and differential screening of amplification products (Souer et al. 1995). This procedure yielded 10 distinct classes of cloned DNA fragments flanking a dTph1 copy in three an11-W137 plants, but not in a homozygote for the An11-T2141 reversion allele. One of these clones, R24, was fully linked to the an11 locus in a plant family segregating for an11-W137 and An11-T2141. This clone was used to probe DNA gel blots containing genomic DNA isolated from plants harboring five independent revertant alleles and from closely related an11-W137 plants. Figure 2 shows that R 24 hybridized to a fragment of $0.5 \mathrm{~kb}$ in homozygotes for independent $A n 11^{+}$reversion alleles or the stable recessive an11-W134 allele, whereas a 300-bp larger fragment, indicative of $d T p h 1$ insertion, was detected in closely related an $11-W 137$ homozygotes. Plants heterozygous for an11-W137 and a revertant allele contain both fragments. Because no other hybridization was detected, we conclude that the cloned $d T p h 1$-flanking sequence R24 corresponds to the an11 locus.

\section{The anll gene encodes a WD-repeat protein}

A cDNA library made from petal limb RNA was screened with R24 to isolate the corresponding cDNA clones. Comparison of the cDNA and the genomic sequences, isolated by means of inverse PCR, showed that the an 11 gene lacks introns (Fig. 3A). The cDNA contains a 1011-bp open reading frame, predicting a protein of 337 amino acids with a molecular mass of $37.8 \mathrm{kD}$. Comparison of the deduced AN11 protein sequence with those contained in the Genbank and EMBL databases revealed a significant sequence similarity with WD-re-

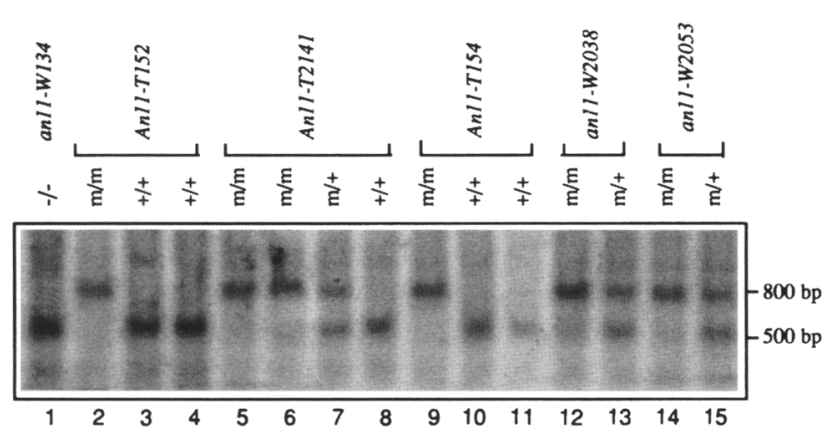

Figure 2. Identification of a $d T p h 1$ flanking sequence derived from an11. Genomic DNA isolated from plants with different an11 genotypes was digested with RsaI and hybridized with the $d T p h 1$ flanking sequence R24. Genotypes are indicated above the lanes, where + denotes a (partial) revertant an 11 allele, $\mathrm{m}$ denotes the mutable an11-W137 allele, and - denotes a stable recessive an 11 allele. The bars indicate sets of closely related plants. R24 hybridizes to an 800-bp fragment in all plants harboring an an11-W137 allele and derived stable alleles generate a 500-bp hybridizing fragment.
A

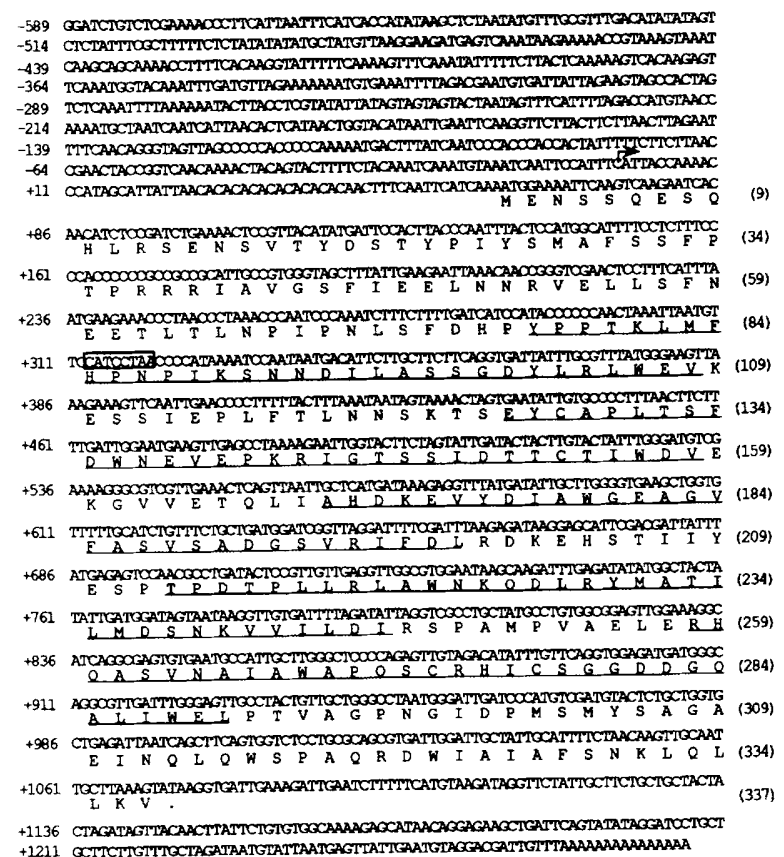

B

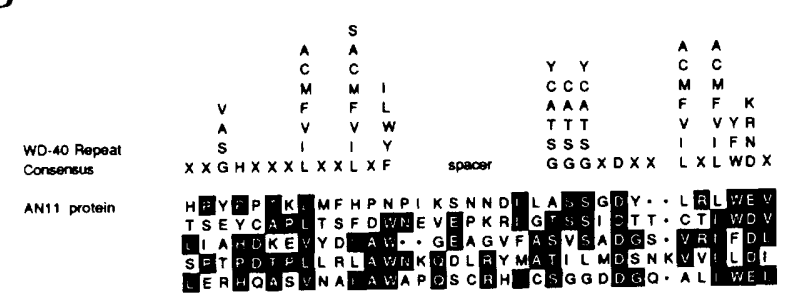

Figure 3. The nucleotide sequence and predicted amino acid sequence of the an11 gene. $|A|$ Nucleotide sequence and translation of the longest open reading frame of the an11 gene. The putative transcription start site (position +1 ) that matches the consensus sequence for plant genes (C/TTCATCA) (Joshi 1987), is indicated by the arrow. The numbers to the left and right refer to the DNA and amino acid residues, respectively. The target site duplication sequence found in the $d T p h 1$ insertion alleles is boxed. Amino acid residues that constitute the WD-repeats are underlined. $|B|$ The WD-repeats of the predicted AN11 protein sequence are aligned by use of published criteria (Neer et al. 1994). Identical amino acids in different repeats (black boxes). The WD-repeat consensus sequence is shown at the top, where $X$ connotes any amino acid.

peat proteins, in particular with the mammalian G-protein $\beta$-subunits and the yeast MSI1 and PRP4 proteins (for review, see Neer et al. 1994). The homology lies in the WD-repeat motif, a 40-43 amino acids tandem repeat usually punctuated with Trp-Asp (WD) residues (Neer et al. 1994). A more detailed inspection of the predicted AN11 amino acid sequence revealed the presence of five WD-repeat motifs (Fig. 3B). WD-repeats consist of a conserved amino- and carboxy-terminal core structure and are separated by short stretches of amino acids that vary 
in length and sequence. In many WD-repeats, including those of AN11, the amino-terminal part with the amino acids $(\mathrm{G} / \mathrm{S} / \mathrm{A} / \mathrm{V}) \mathrm{H}$ has diverged considerably from the consensus, whereas the carboxy-terminal part is usually much better conserved. Neer et al. (1994) stated that WD-repeat proteins, by definition, have at least one repeat that matches the consensus with zero or one mismatches, and at least one repeat with three or fewer mismatches. Consistent with these criteria, three of the five repeats $(2,3$, and 5$)$ of the AN11 protein have one or two mismatches with the consensus core repeat sequence, whereas the remaining two repeats ( 1 and 4$)$ each have five mismatches. The length of the core between the $\mathrm{GH}$ and WD sequences in each WD-repeat of AN1 1 protein is 26-28 amino acids, which is also consistent with the consensus (Neer et al. 1994).

\section{Spatiotemporal and genetic control of an 11 expression}

To study the pattern of an11 gene expression, we measured an11 mRNA levels in various tissues relative to mRNA levels of $d f_{r}$ (an an11 controlled structural anthocyanin gene encoding dihydroflavonol 4-reductase), chs (a structural gene encoding chalcone synthase that is coordinately expressed with $d f r$, but not controlled by an11) and gapdh (encoding the glycolytic enzyme glyceraldehyde 3-phosphate dehydrogenase). Figure 4A shows that an 11 mRNA levels in the limb of developing petals closely parallel those of $d f r$ and chs. The three mRNAs increase from a low level in young (stage 1) buds to a maximum in stage $4 / 5$, when the petal starts to unfold. From this stage on, the $d f r$ and chs mRNA quickly disappear, whereas the an 11 mRNA level decreases only slightly. In the flower tube, however, an 11 , chs, and dfr mRNA accumulation is not completely parallel, even though they reach a maximum at the same stage (5).

In anthers, chs and $d f_{r}$ genes are coordinately expressed at a slightly earlier stage of flower development than in the petals (Beld et al. 1989). Figure 4A shows that chs mRNA levels in anthers display a steep increase from stage 1 to 3 , whereas an 11 mRNA levels are virtually constant during that period. Because the R27 line used for these experiments is an $a n 4^{-}$mutant, no $d f_{r}$ mRNA is detected in the anthers (Quattrocchio et al. 1993). Ovaries express an11 throughout development in a pattern very similar to that of chs and $d f r$. Strikingly, we also detected an11 transcripts in sepals, leaves, stems, and roots. These tissues are normally not pigmented, consistent with the absence of chs and dfr expression.

To determine whether an 11 expression is controlled at the transcriptional level by the two other anthocyanin regulatory loci an 1 and an2, we measured an 11 transcript levels in $a n 1^{-}$and $a n 2^{-}$mutants (Fig. 4B, left). Comparison of the an 11 mRNA level in the line W138, harboring the unstable an1-W138 allele, with that in the isogenic wild-type R27, shows that the an1 mutation has no significant effect on an11 expression. Similarly, the an11 mRNA level in the an2 ${ }^{-}$mutant W115 is compa-
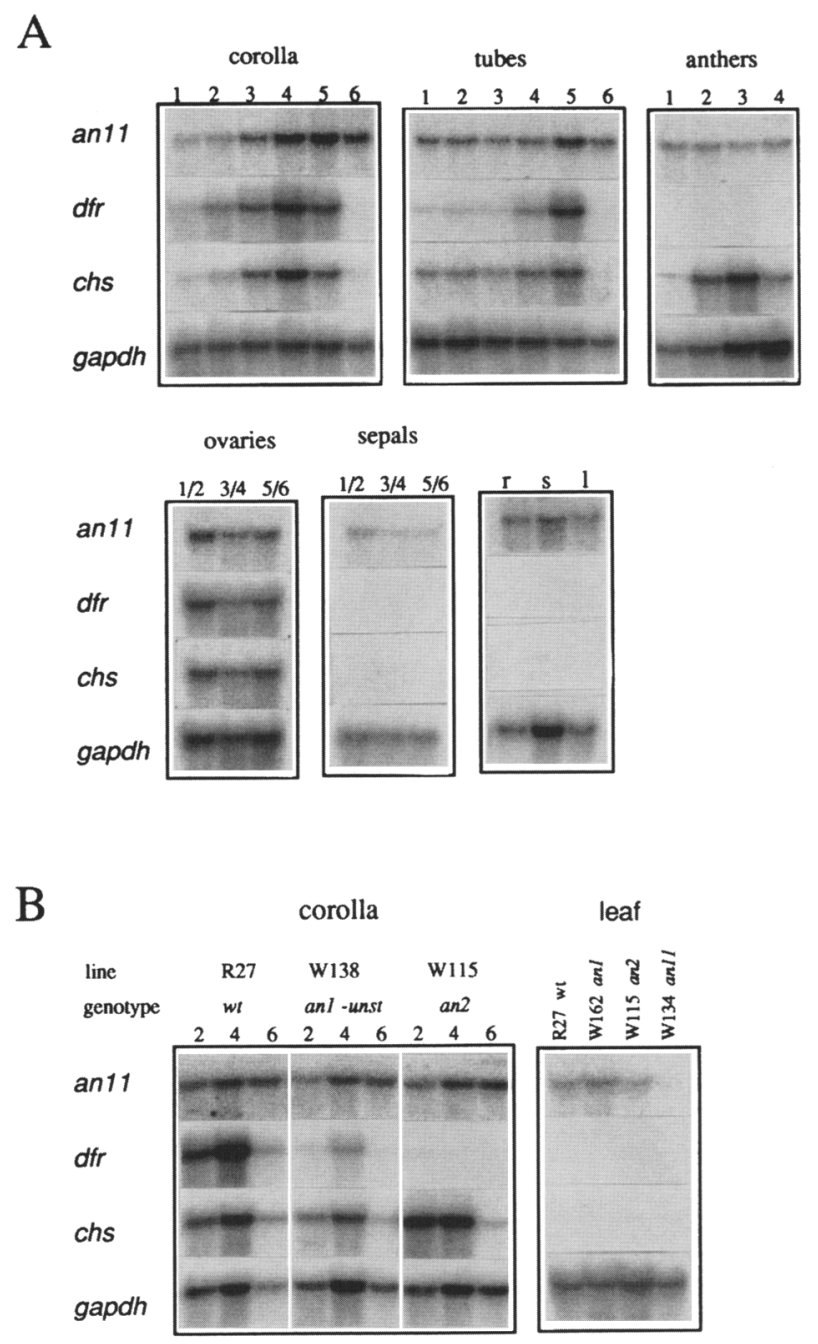

Figure 4. Spatiotemporal and genetic control of an11 expression. (A) RNA gel blot analysis of total RNA from floral organs at different developmental stages $(1-6)$ as indicated and from root $\langle r|$, stem $\langle s\rangle$, and leaf $(1)$. The filters were sequentially hybridized with an 11, dfr, a structural gene regulated by an 11 and chs, a gene encoding for an anthocyanin biosynthesis enzyme and not regulated by an11, and gapdh to confirm the presence of RNA in all lanes. $(B)$ Genetic control of an 11 expression in the flower corolla and leaves by the regulatory loci an 1 and an2. RNA was isolated from corollas from various petunia lines at three developmental stages. The petunia lines used and their genotype are indicated above the lanes.

rable to that in the nonisogenic wild-type R27. As expected, the $d f_{r}$ mRNA levels are very low in the an1 and an2 mutants. In leaves, an 11 also appears to be expressed independently from the regulators an1 and an2 (Fig. 4B, right|. No signal was detected in an $11^{-}$leaves, indicating that the transcripts detected in vegetative tissues are indeed derived from the an 11 locus.

Taken together, these data show that the spatiotemporal expression of an11 and that of the target genes $|d f r|$ are not correlated; an11 is expressed in pigmented as well as unpigmented tissues. Furthermore, it seems un- 
likely that the other two regulators, an 1 and an2, control $d f r$ transcription by controlling an 11 mRNA levels.

\section{Analysis of mutant anl 1 alleles}

As a first step toward defining the functional important domains in the AN11 protein, we analyzed the different alleles derived from an11-W137 (Fig. 5A). Mapping and sequence analysis of the an11-W137 allele showed that the $d T p h 1$ element was inserted in the first WD-repeat, (321-bp downstream of the transcription start site, see Fig. 3A). The $d T p h 1$ element was flanked by an 8 -bp duplication of an11 sequence, a structure similar to dTph1 insertions in other genes (Gerats et al. 1990; Souer et al. 1996). Sequence analysis of four stable an $11^{-}$derivative alleles showed that $d T p h 1$ had excised and generated a 5- or 8-bp footprint causing a frameshift. This frameshift results in the addition of 4 or 5 novel amino acids after Pro- 86 before a stop codon is reached. Conceptual translation of these transcripts produces proteins lacking the WD-repeats. The partial revertant alleles an11-W2038 and an11-W2053 both have a 3-bp insertion after Pro-86, which leads to an extra Asp. Three independent revertant alleles have been isolated, each having a 6-bp footprint. The footprints in An11-T2141 and An11-T152 are identical, conceptually leading to a Pro-Ile insertion between His- 85 and Pro-86. The 6-bp footprint in An11-T154 would cause the insertion of a Pro-Asp at the same position.

PCR and sequence analysis showed that in an11G5543, 4 bp was deleted immediately upstream the dTph1 element in an11-W137. Most likely, an11-G5543 arose by an unsuccessful $d T p h 1$ transposition event, in which the $d T p h 1$ element was cleaved at the left end, but not at the right, followed by ligation. This 4-bp deletion apparently results in a slightly different spectrum
A

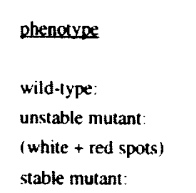

stable mutant:

partial revertant:

reverant:

unstable mutant:

(white + pink sposs)

partial revertant: allele

An $1 \cdot$ R27

an11-W137

an $11 \cdot T 150$

an $11 . T 155$

an11.X2197

an11-W134

an 11-W2038

an $11 \cdot$-W2053

AnII-T2141

An11-T152

An11.T154

an11-G5543

an11-Z2297
DNA sequence

CATCCTAACCCC

CATCCTAA $A T$ T $h 1>C$ ATCCTAACCCC

CATCCTA TG ATCCTAACCCC

CATCCTA TG ATCCTAACCCC

CATCCTA TG ATCCTAACCCC

CATCCTA

CAT

CAT

CATCCTA

CATCCTA

CATCCT

CAT

\section{Ga tCCTAACCCC}

TCCTAACCCC

TCCTAACCCC

TCCTAACCCC

Tphl>CATCCTAACCCC

GA

TCCTAACCCC
B

amino acid sequence

HPNP

HPMILTP*

HPMILTP *

HPMILTP *

HPILTP.

HDPNP

HDPNP

HPIPNP

HPIPNP

HPD PNP

HDPNP

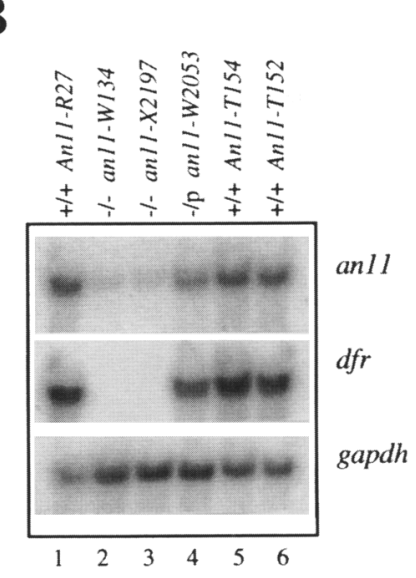

C

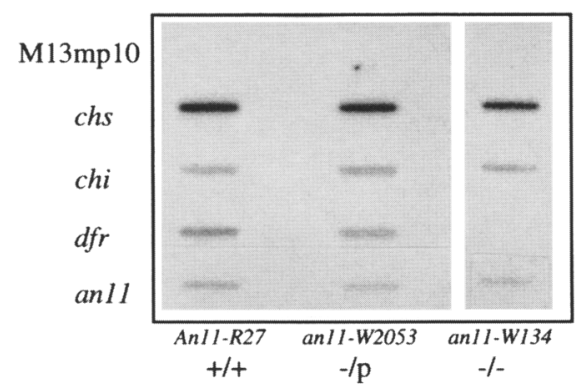

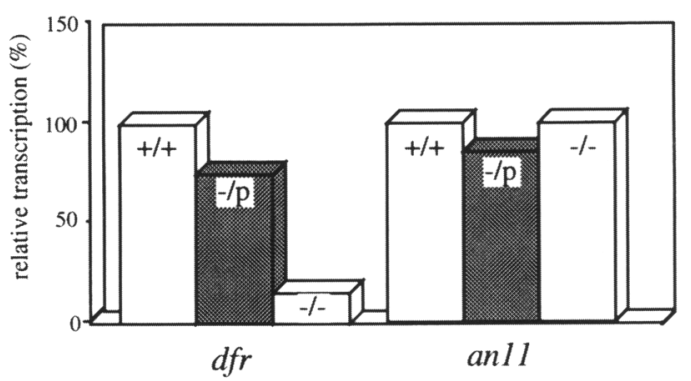

Figure 5. Analysis of an11 alleles. $|A|$ Footprint alleles generated after excision of the $d T p h 1$ element from the an11-W137. Comparison of the DNA and deduced amino acid sequences of wild-type (An11-R27), an11-W137, stable mutant, partial revertant, and full revertant $A n 11$ alleles. The 8-bp target site duplication upon $d T p h 1$ insertion are underlined. $(B)$ Expression of an 11 in various mutant, partial, and full revertant $A n 11$ alleles. Total RNA was isolated from R27 (wild-type), two independent stable an11 mutants (W134, X2197), a partial revertant (W2053), and two independent An11 revertants. Blots were probed with an11, dfr, and gapdh. (C) Analysis of the transcription initiation of chs, chi, $d f r$, and an 11 in wild-type, partial revertant and mutant an 11 alleles. Nuclear run-on assays were performed utilizing nuclei of corollas in developmental stage $3 / 4$. Nascent ${ }^{32} \mathrm{P}$-labeled RNAs were hybridized to filters carrying single-stranded DNA clones of indicated genes. Empty M13mp10 vector was loaded as a control. Quantitation of the $d f r$ and an11 signals are shown in the histogram, which gives the relative transcription rates expressed as the $d f_{r}$ to chs, and the an11 to chs signal ratios. 
of excision footprints, and a different ratio of full (red) and partial (pink) revertant spots. Sequencing of the sporogenic partial reversion allele an11-Z2297 derived from an11-G5543 showed that its sequence was identical to an11-W2038 and an11-W2053. RNA gel blot analysis of plants harboring mutant alleles (Fig. 5B) shows that flowers homozygous for the stable recessive alleles an11W134 and an11-X2197, produce very little an11 mRNA. The partial revertant an11-W2053 has an intermediate an11 transcript level /threefold lower than in R27 wild type), whereas the full revertants An11-T152 and An11T154 have an11 mRNA levels comparable to that of the R27 wild-type plant. An identical pattern was obtained after hybridization with the an11-controlled gene, $d f r$.

To test whether the reduced levels of an 11 mRNA in the an11- mutant are the result of reduced an11 gene transcription or destabilization of the an11 transcript, we analyzed nascent RNA by a nuclear run-on assay for an11, dfr, chs, and chi (encoding chalcone flavanone isomerase). chs and chi were used as an internal control to normalize the an11 and $d f r$ signals, because they have a similar temporal expression pattern in the petal limb but are not controlled by an 11 . Figure $5 \mathrm{C}$ shows that the transcription rate of the $d f_{r}$ gene was reduced in the partial an 11 revertant and an $11^{-}$line as expected, whereas the rate of transcription of the an 11 gene remained comparable to that in the wild-type R27. These results indicate that the mutations result in destabilization of the an11 transcript. This is in agreement with the observation that an an 11 promoter- $\beta$-glucoronidase (gus) fusion is equally expressed in particle bombarded $A n 11^{+}$and an11-W134 petals (data not shown).

\section{AN11 protein is localized in the cytosol}

To examine the subcellular localization of AN1 1 protein in the petunia corolla, we raised a polyclonal antiserum against the AN1 1 protein. The AN11 ORF was expressed in Escherichia coli with the pRSET expression vector. The IPTG-induced His tag/AN11 fusion polypeptide migrated at $40 \mathrm{kD}$ and was purified by nickel affinity chromatography (Fig. 6A, lanes 2-6). Anti-AN11 serum reacted specifically with a protein doublet of $40 \mathrm{kD}$ present in wild type (R27), but not in an11-W134 corolla limbs (Fig. 6A, lanes 7,8). The presence of two proteins crossreacting with the anti-AN11 antiserum with little difference in molecular size could be caused by post-translational modification or proteolytic cleavage of the AN11 polypeptide.

The subcellular localization of the AN11 protein was determined by fractionating petal extracts into a cytosolic, microsomal membrane and nuclear fraction and immunological detection of the protein (Fig. $6 \mathrm{~B}$ ). Incubation with anti-AN11 antibodies showed that the $40-\mathrm{kD}$ AN11 protein was found predominantly in the cytosolic fraction of wild-type R27 corolla limbs, not in the microsomal membrane fraction or in the nucleus. To assess the purity of the protein fractions, we subsequently used the same blot to probe with anti-F3H antiserum [detects the flavonoid biosynthetic enzyme flavanone 3-hydrox-

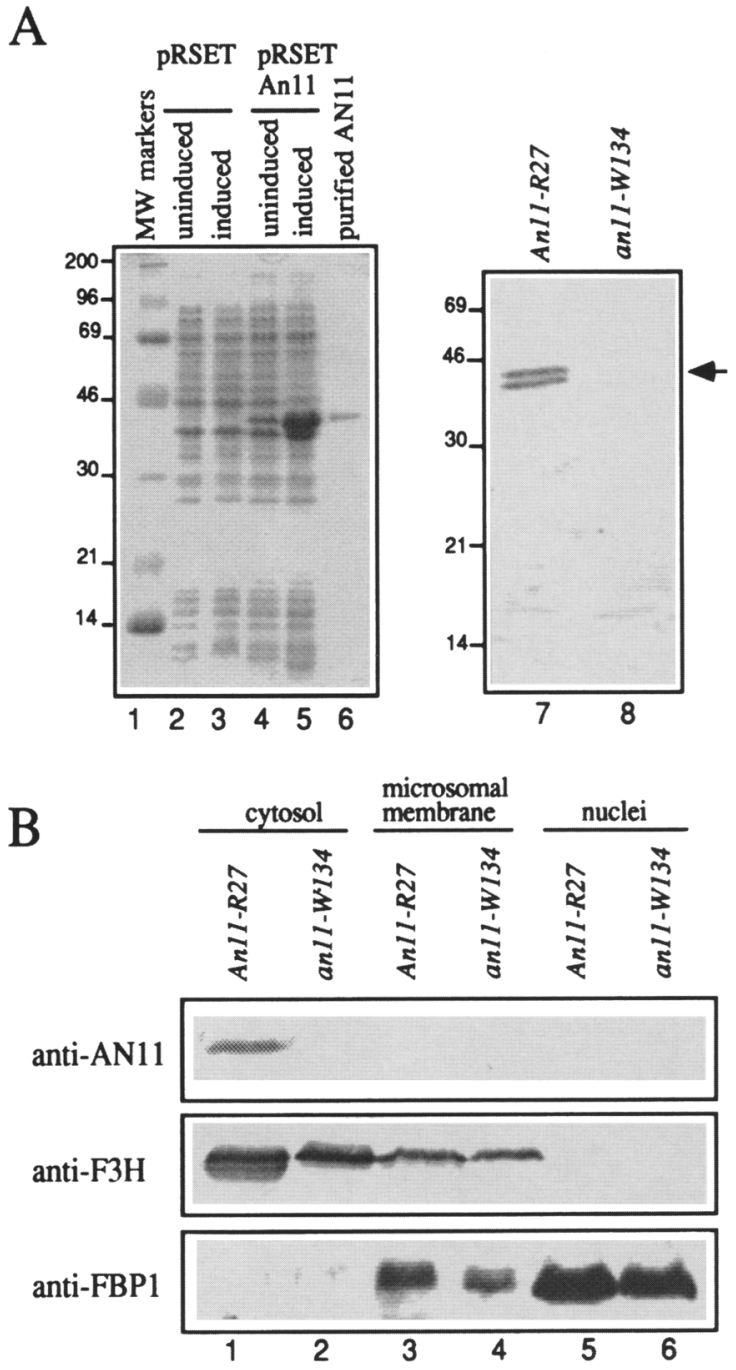

Figure 6. Subcellular localization of AN1l protein. $(A)$ Expression of AN11 fusion protein in E. coli. SDS-polyacrylamide gel electrophoresis showing protein extracts from $E$. coli containing (lanes 4,5) or lacking (lanes 2,3) the an 11 cDNA. Bacteria were either induced (lanes 3,5) or uninduced (lanes 2,4) with IPTG, and AN1 1 was affinity purified by use of the histidine tag (lane 6). Lane 1 contains molecular mass standards. Numbers on the left are given in $\mathrm{kD}$. Anti-AN11 antibodies recognize AN11 protein in wild-type $\mathrm{R} 27$ petunia corolla, not present in the an 11- mutant W134. Total protein extracts from wild-type flane 7) and an $11^{-}$mutant (lane 8) corollas were separated on SDSPAGE and transferred to nitrocellulose. Filters were incubated with anti-AN11 antiserum and AN11 protein was detected by an enhanced chemiluminescence detection method. $(B)$ Subcellular localization of AN11. Proteins isolated from the cytosolic (lanes 1,2), microsomal membrane (lanes 3,4) and nuclear fraction (lanes 5,6 ) of wild-type R27 (lanes $1,3,5$ ) or an $11^{-}$mutant W1.34 (lanes 2,4,6) petunia flower corolla were separated on an SDS-polyacrylamide gel and AN11 protein was detected by immunoblotting with AN11-specific antiserum. The same filter was subsequently incubated with antiserum raised against $\mathrm{F} 3 \mathrm{H}$ (a cytosolic localized enzyme of the anthocyanin biosynthesis pathway) and FBP1 (a nuclear localized MADS box protein). 
ylase (Britsch et al. 1991)] and anti-FBPl antiserum [detects a nuclear localized MADS box protein (Cañas et al. 1994)]. Anti-F3H antiserum recognized a $38-\mathrm{kD}$ protein predominantly present in the cytosolic fraction and also in the microsomal membranes. The anti-FBP1 antibodies recognize the $25-\mathrm{kD}$ FBP1 protein in the nucleus of both wild-type R27 and W134 an11- mutant corolla limbs, whereas no protein is detected in the cytosolic protein fraction. The presence of FBPl protein in the microsomal membrane fraction suggests that this fraction is slightly contaminated with nuclei. These data show that the cytosolic and nuclear fractions have very little cross-contamination. We conclude that the AN11 protein is predominantly present in the cytosol.

\section{AN11 is evolutionary conserved among eukaryotes}

For a number of WD-repeat proteins, conserved homologs with similar function have been identified in different species. According to the sequence criteria of Neer et al (1994), none of the WD-repeat proteins in the GenBank and EMBL databases can be considered as an an11 ortholog. Therefore, we tested whether an 11 homologs exist in other eukaryotic species by Southern blot analysis. Figure 7 shows that an 11 hybridizes to single EcoRI or HindIII fragments in petunia, maize, Chlamydomonas, yeast, Caenorhabditis elegans, and human. It would

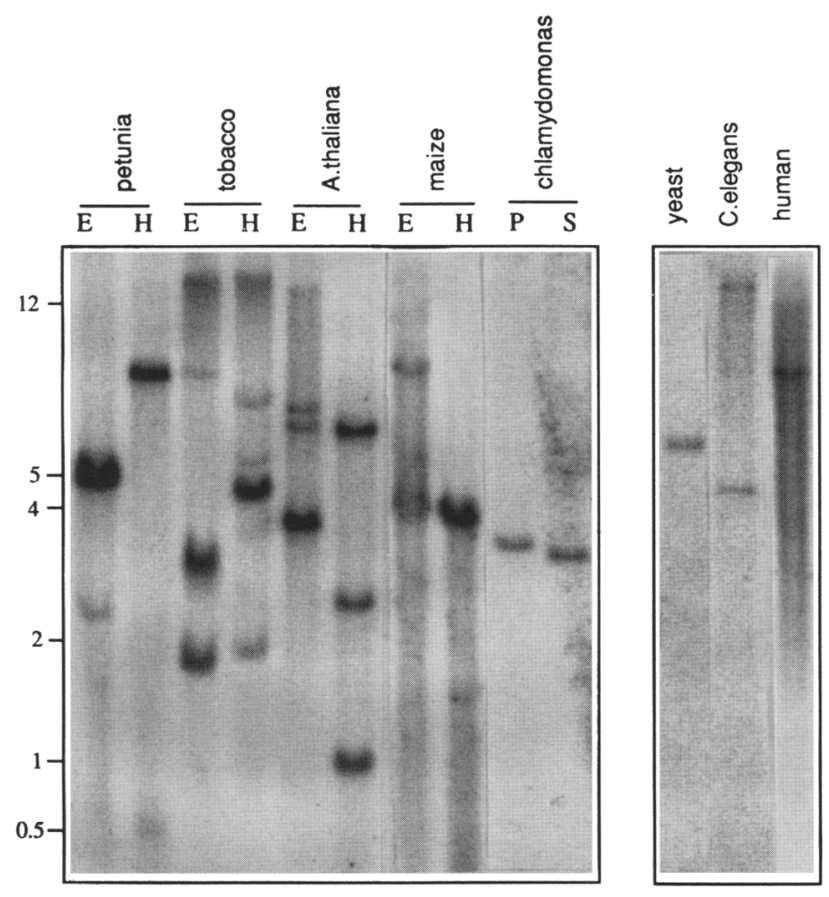

Figure 7. The presence of an 11 homologs in different eukaryotic species. Total genomic DNA from different eukaryotes was digested with EcoRI (E), HindIII (H), PstI (P), or SaII (S), electrophoresed and blotted to Hybond N+. Genomic DNA isolated from yeast, C. elegans, and human was digested with EcoRI. Blots were probed with the petunia an11 CDNA and washed with $0.5 \times \mathrm{SSC}$ at $60^{\circ} \mathrm{C}$. seem, therefore, that these species contain a single an 11 homologous gene. Three hybridizing fragments were detected in Arabidopsis, whereas in tobacco a number of strong and weaker hybridizing bands were observed, indicating the presence of multiple an 11 homologs.

In a search of the entire yeast genomic sequence we found only one gene, which we designated Scan11, with high homology to an11. The restriction sites surrounding Scan11 match the sizes of the fragment seen on Southern blots of yeast DNA. This indicates that Scan11 is the closest an 11 homolog in the yeast genome. Subsequent searches of the National Center of Biotechnology Instruction (NCBI) database revealed sequences in the genomes of Arabidopsis, C. elegans, and human with even higher homology to an11. In Arabidopsis, two expressed sequence tags (ESTs) and one genomic open reading frame (ORF) were identified, consistent with the number of hybridizing fragments on the Southern blot (Fig. 7). The genomic ORF, designated Atan $11-b$, is located on chromosome 3 , upstream of the gapdhA gene and lacks introns. The cDNA, Atan11-a, corresponding to one of the ESTs was fully sequenced. A human cDNA with high homology to an11 appears in various EST libraries prepared from heart, placenta, liver, spleen, fetal lung, and brain tissue, suggesting that the gene is expressed in a wide variety of tissues. A full-length cDNA, Hsan11, was amplified from a cDNA library with primers derived from the ESTs and fully sequenced. A C. elegans an11 homolog, Cean11, had been sequenced by the genome consortium and has at least four introns. Because of a lack of homology between the $5^{\prime}$ end of the coding sequence of Cean 11 and the other an 11 homologs and the possible presence of an intron in this region of the Cean11, we have been unable to locate the translational start of Cean11.

Except for SCAN11, all AN11 homologous proteins have similar sizes. They all contain five WD-repeats at corresponding positions (Fig. 8A) and the sequence similarity extends across the WD-repeats and the carboxyl terminus. The yeast SCAN11 protein is almost 200 amino acids larger, mainly caused by the considerably larger spacing between the WD-repeats, and an aminoterminal extension. In pairwise comparisons, the AN1 1 proteins have $26 \%$ (yeast) to $59 \%$ (Arabidopsis) overall sequence identity with the petunia AN11. A phylogenetic tree of the AN11 homologous amino acid sequences shows that the mammalian and plant sequences are more related to each other, whereas the yeast SCAN11 appears to represent a separate branch.

To test whether the observed sequence similarities between an11 homologs reflect functional similarity, we examined whether they could complement the an $11^{-}$ mutation in petunia. Therefore, the coding sequences of the petunia, Arabidopsis, human, and yeast an11 homologs were fused to the strong and constitutive $35 \mathrm{~S}$ promoter from cauliflower mosaic virus (CaMV). To measure the activity of these constructs, we used a luciferase (luc) reporter gene fused to the $d f_{r}$ promoter. The effector (35S-an11 homolog fusion) and reporter gene were cointroduced into petunia an11-W134 petal cells 
A

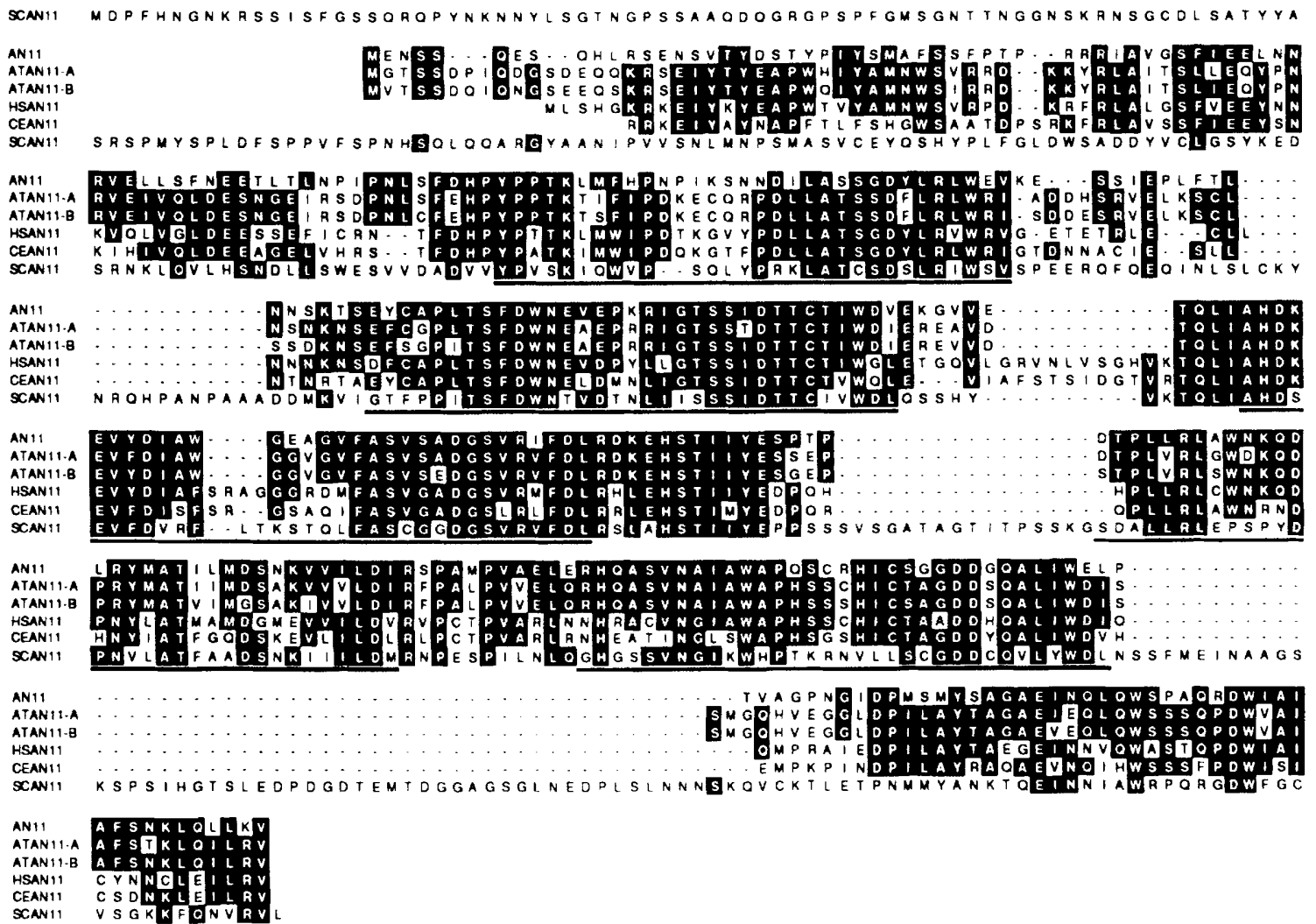

B

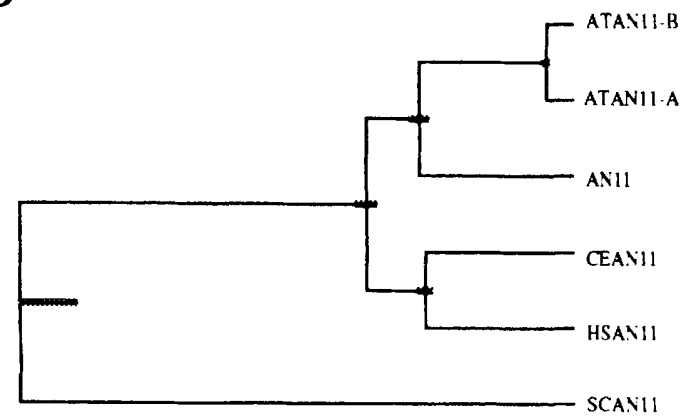

C

$\begin{array}{lcc}\text { Effector } & \text { LUC/GUS } & \text { Fold.Ack } \\ \text { none } & 0.15 \pm 0.05 & \\ 35 S \text {-anll } & 12.2 \pm 6.2 & 81 \pm 41 \\ 35 S \text {-Atanll-a } & 1.13 \pm 0.67 & 7.5 \pm 4.5 \\ 35 S \text {-Hsanll } & 0.82 \pm 0.11 & 5.4 \pm 0.7 \\ 35 S \text {-Scanll } & 0.12 \pm 0.08 & 1.0 \pm 0.5\end{array}$

;ure 8. Comparison of ANl I from plants, mammals and yeast. |A| Alignment of the petunia AN11 sequence with homologs from: ccharomyces cerevisiae (SCAN11), Arabidopsis thaliana (ATAN11-a and ATAN1l-b), Homo sapiens (HSANI1), and Caenorhabis elegans (CEAN11). Identical amino acids present in three or more sequences (black boxes). WD-40 domains (underlined). Dots resent gaps for optimal alignment. The sources of the sequences are: AN11, this work; ATAN11-a, this work; ATAN11-b, Arabipsis Genome Consortium; CEAN11, C. elegans Genome Consortium cosmid F53C11; SCAN11, Yeast Genome Consortium. (B) ylogenetic tree of the AN11 homologs. All sequences were truncated to the same length as the CEAN11. The standard errors licate the validity of the branch points as determined by the algorithm within the UPGMA program utility of GeneWorks (Intelenetics). This tree shows potential evolution or functional relationship among the sequences described in $A$. $(C)$ Complementation an $11^{-}$mutants flowers by AN11 homologs. An11. Atan11-a, Hsan11, and Scan11 cDNAs were fused to the 35S promoter and ;roduced in an11-W134 corolla limbs by particle bombardment. Activity was measured with a dfr-luc reporter gene and standard¿d using a chs-gus fusion gene to assay transformation efficiency. The values represent the mean of four independent bombardments. rors shown are the standard error of the mean. 
by particle bombardment. Figure $8 \mathrm{C}$ shows that cobombardment of the petunia an 11 gene with $d f r-l u c$ in the an $11^{-}$mutant corolla resulted in strong activation of the $d f r-l u c$ reporter gene. The level of activation is more than 80-fold over the basal expression. The Arabidopsis and human AN11 activated the $d f r-l u c$ reporter, albeit at a 10 -fold lower efficiency, whereas the yeast AN11 homolog was inactive. These results indicate that the human and Arabidopsis an 11 homologous sequences are functional an 11 homologs. The yeast Scan11 might be too diverged to be functional in plants or not translated sufficiently in plants.

dfr promoter activity is restored in an an $11^{-}$mutant by overexpression of the MYB-type transcription factor AN2

The cytosolic localization and the nature of the AN11 protein make it unlikely that AN11 is a DNA-binding protein, but that it is more likely to exert its action through the putative transcription factors AN1 and/or AN2, resulting in the activation of the anthocyanin biosynthesis pathway. If this is true, one would predict that expression of the AN1 or AN2 protein in the an11- mutant corolla would overcome the absence of AN11. To test this hypothesis, an 1 and an 2 cDNAs fused to the CaMV-35S promoter were coexpressed with the $d f r_{-}$ luc reporter gene in the an $11^{-}$mutant W134. Table 1 shows that overexpression of an 2 in the an $11^{-}$mutant induced $d f_{r}-l u c$ activity 12 -fold, similar to the activation by the AN11 protein. The AN1 protein was unable to activate the $d f r$ promoter (data not shown). The reverse experiment, introduction of $35 S-$ an 11 in an $2^{-}$petals, did not reactivate the $d f r-I u c$ reporter. These results are consistent with previously published results (Quattrocchio et al. 1993), showing that $d f r$ promoter activity in an $11^{-}$ petals could be restored (though with low efficiency) by the maize an 2 homolog $c 1$, but not by $l c$, encoding the maize bHLH protein. Taken together, these data indicate that AN11 acts upstream of AN2.

\section{Discussion}

Over the last few years, a number of regulatory anthocyanin genes have been identified in maize, petunia, and snapdragon. So far, they all encode transcription factors with an MYB or a bHLH domain (for review, see Mol et

Table 1. Complementation of the an11-W134 mutant by AN2

\begin{tabular}{llllll}
\hline & \multicolumn{2}{c}{ an11-W134 } & & \multicolumn{2}{c}{ an2-W115 } \\
\cline { 2 - 3 } Effector & LUC/GUS $^{\text {N }}$ & fold. act. & & LUC/GUS & fold act. \\
\hline None & $0.44 \pm 0.44$ & & & $0.85 \pm 0.27$ & \\
35S-an2 & $5.31 \pm 2.63$ & $12 \pm 5.9$ & & $29.0 \pm 15.3$ & $34 \pm 18$ \\
$35 S$-an11 & $4.88 \pm 2.42$ & $11 \pm 5.5$ & & $1.27 \pm 1.21$ & $1.5 \pm 1.4$ \\
\hline
\end{tabular}

${ }^{\text {a Ratio of } d f r-l u c \text { activity/chs-gus in arbitrary units; mean } \pm \text { S.E. }}$ $(n=4)$. al. 1996). Here we show that the regulatory anthocyanin gene of petunia an11 encodes an evolutionary conserved WD-repeat protein that is primarily localized in the cytosol. In transient expression assays, overexpression of the MYB domain protein AN2 in an11- petals can restore the promoter activity of the $d f r$ gene, indicating that AN1 1 acts upstream of AN2. We propose that AN11 is involved in a signal transduction cascade leading to activation of $\mathrm{AN} 2$.

an 11 encodes a WD-repeat protein that is conserved in nature

WD-repeat proteins represent a family of regulatory proteins that have been implicated in a variety of processes like cell-cycle control, signal transduction, RNA splicing, and vesicular trafficking (Neer et al. 1994). WD-repeat proteins, in general, seem to have a regulatory function; no member of this class of proteins has yet been shown to have catalytic activity (Neer et al. 1994). The WD-repeat structure may facilitate interaction with other proteins, consistent with the observation that many of these proteins are found in multi-protein complexes as shown for the $\beta$-subunit of the heterotrimeric G protein (for review, see Neer and Clapham 1988), protein phosphatase A2 (Kamibayashi et al. 1992) and yeast TUP1 (Komachi et al. 1994). Such protein-protein interaction could result in a protein-induced conformational change, leading to activation of the complex. Some WD40 proteins, like RACK1, are made up entirely of WDrepeats (Ron et al. 1994). Others, including AN11, contain amino-terminal and carboxy-terminal extensions of various lengths, which may contribute to the regulatory function, as shown for the G- $\beta$ subunit and the phospholipase A2 activating protein (Clark et al. 1991; Garritsen et al. 1993).

Apart from the relatively loose WD-repeat consensus sequence, no significant sequence homology has been found between ANII and any other identified WD-repeat protein, indicating that AN11 is a new member of this rapidly expanding family of proteins. Based on three criteria, WD-repeat proteins are grouped into subfamilies that presumably define functional homologs (Neer et al. 1994). First, the proteins must have the same number of WD-repeats. Second, the WD-repeats, at equivalent positions in other subfamily members, should be more similar to each other than to any other repeat. Third, the homology must stretch beyond the repeating units into the amino- and carboxy-terminal extensions. So far, five subfamilies have been identified that meet these requirements: (1) the family of G- $\beta$ subunits, (2) the nuclear neurogenic Groucho-related proteins, $(3)$ protein phosphatase regulatory subunits, and $(4)$ a group defined by the protein kinase C-binding protein RACK1 (Neer et al. 1994l. Recently, a fifth subfamily has been proposed consisting of HIRA and HIRl repressors of transcription of the histone core genes $\mathrm{H} 2 \mathrm{~A}$ and $\mathrm{H} 2 \mathrm{~B}$ (Lamour et al. 1995). The AN11 protein defines a sixth subfamily of functionally related WD-repeat proteins, present in yeast, animals and plants (Figs. 7,8 ). These proteins sat- 
isfy the three sequence criteria that identify functional homologs. Functional homology is substantiated by complementation of the petunia an 11 mutation with the human and Arabidopsis an11 homologs.

Given that AN11 homologs presumably coevolved with yet unknown partners, it is remarkable that proteins from distant species are apparently still capable of recognizing the petunia ANll partner. Therefore, it is not surprising that the most diverged AN11 homolog, SCAN11 from yeast, does not complement the an11mutation, as it may simply fail to complex with the petunia AN1 1 partner.

\section{Role of AN11 in the regulation of anthocyanin} biosynthesis

Mutations at the an11 locus affect two seemingly unrelated processes: transcriptional inactivation of the anthocyanin-specific genes resulting in a loss of pigmentation, and the control of intracellular $\mathrm{pH}$ in petal cells (Quattrocchio et al. 1993; 1994). Strikingly, the an11 gene is expressed in a wide variety of tissues including tissues that are not anthocyanin pigmented. Thus, an 11 is unlikely to determine the pattern of pigmentation. Because no obvious phenotypic alterations are seen in leaves, stem, and roots, the function of an11 in these tissues, if any, is unclear. It seems unlikely that an 11 function is redundant in these tissues as genomic DNA gel blots indicate that an11 is a single copy gene.

Mutations at the an1 and an2 locus have similar effects, although an $2^{-}$mutations only affect pigmentation of the corolla. The products of these genes share homology with MYB and bHLH proteins indicating that they are putative transcription activators. Because AN11 is predominantly localized to the cytoplasm, it is unlikely to be part of a transcription complex. This, together with the observation that $d f r$ promoter activity in an $11^{-}$petals could be restored by overexpressing the AN2 protein, suggests that AN11 acts upstream of the putative transcription factor AN2.

We can envisage a number of scenarios to explain the restoration of $d f_{r}$ promoter activity. The simplest explanation, the transcriptional regulation of an 2 by AN1 1 , can be excluded, because the levels of an 2 mRNA in wild-type and an11- flowers are similar (Quattrocchio 1994). Thus, AN11 is more likely to be involved in the post-translational control of AN2, either by modifying the AN2 activity or its cellular localization. For instance, an increased level of AN2 may simply compensate for a lower DNA-binding affinity or transcription activation potential. It has been shown for plant and animal MYB-domain proteins that phosphorylation reduces DNA-binding activity (Lüscher et al. 1990; Moyano et al. 1996) and in addition a WD-repeat protein has been identified as the regulatory subunit of a protein phosphatase (Mayer et al. 1991). Alternatively, AN11 could have a role in nuclear transport of AN2. The hydrophilic nature and the cytosolic localization of AN1 1 argue against the notion that $\mathrm{AN} 11$ functions as a receptor for AN2. It is possible, however, that AN11 maintains $\mathrm{AN} 2$ in, or con- verts it into, an import-competent form. It is noteworthy in this respect that a WD-repeat protein, PAS7, has been shown to be involved in the import of thiolase into peroxisomes (Marzioch et al. 1994). Post-translational regulation of AN2 by AN11 could explain the substantial time lag between the appearance of an2 mRNA and the induction of the $d f r$ structural gene during petal development (F. Quattrocchio, J. Wing, K. van der Woude, J. Mol, and R. Koes, in prep.). The timing of $d f_{r}$ induction is, however, closely correlated with the appearance of an11 mRNA (Fig. 4).

\section{Conservation of AN11 during evolution}

The different flavonoid end products serve a wide variety of biological functions and their distribution through the plant kingdom indicates that they appeared sequentially during evolution, thus the appearance of the structural genes and their linking to regulatory networks also occurred stepwise (Koes et al. 1994). On the basis of sequence homologies, it was argued that structural flavonoid genes originated from genes encoding enzymes of primary metabolism (Stafford 1991). There is very little useful information, however, to deduce how and when the regulatory genes appeared.

The best information on the origin of regulatory flavonoid genes that has been obtained so far comes from expression analysis of the chs gene(s). Only in legumes, chs genes are expressed in the root tip where they are involved in the synthesis of flavonoids that serve as signaling molecules for nodulating Rhizobia. In a non-legume host, tobacco, the bean chs promoter is active in the root tip even though the endogenous chs genes are not (Schmid et al. 1990). This indicates that the regulatory networks are more widespread and evolutionary older than the biological function of the flavonoids. One interpretation is that newly appeared or pre-existing structural genes are simply linked to pre-existing regulators (with, e.g., a useful expression pattern) to establish new expression patterns and biological functions for flavonoid biosynthetic genes. Our observation that the an 11 gene is highly conserved in nature, even in organisms that can not synthesize anthocyanins, supports this notion. Before the anthocyanin pathway appeared, an11 presumably controlled an old set of target genes. It is unclear if these old target genes are still functional in a higher plant, and in which process they are involved. In this light, it will be interesting to elucidate the biological functions of the an 11 homologs in species other than higher plants, for instance, by gene replacement of Scan11 in yeast.

\section{Materials and methods}

\section{Plant material}

The an11-W137 allele arose spontaneously in the progeny of the unstable an 1 petunia line W138 (Doodeman et al. 1984). The lines W138 (harboring the unstable an 1-W138 allele) and W137 (harboring the unstable an 11-W137 allele) resulted from $d T p h 1$ insertions in the background of the wild-type line R27. Full revertants $\left\{A n 11^{+}-\right.$T152, An11 $1^{+}-$T154 and $A n 11^{+}-$T152\}, 
partial revertants (an11-W2038 and an11-W2053) and stable null alleles lan11-W134, an11-T150, an11-T155, and an11$X 2197)$ were isolated from selfed progeny of independent an11W137 homozygous plants. The unstable an11-G5543 allele was identified in progeny of a cross between an11-W137 and an11W134 homozygotes on the basis of a novel spotting pattern in the flower, and made homozygous by further selfings. Excision of the transposon from an11-G5543 resulted in the partial revertant allele an11-Z2297. The line W115 contains stable recessive alleles at the an2 and an 4 locus. All plants were kept in a normal greenhouse.

\section{Isolation and DNA sequencing of an 1 CDNA and genomic} clones

Genomic DNA from young petunia leaves was isolated by a standard procedure (Dellaporta et al. 1983) with modifications (Souer et al. 1995). DNA prepared from the an 11 mutable W137 line was used to isolate mutant specific $d T p h 1$-flanking sequences as described (Souer et al. 1995). Briefly, $2 \mu \mathrm{g}$ of DNA from an an11-W137 homozygous plant (plant T2141-10), a pool of siblings homozygous for the An11-T2141 revertant allele and a more distantly related family (V2060) of an11-W137 homozygotes was digested with RsaI, HaelII, or HincII/EcoRV and recircularized by overnight ligation. The first round of amplification was performed with the $d T p h 1$-specific primers out $515^{\prime}$. dCCCTTATTAGAATTCTTGGCTCCGC- $\left.3^{\prime}\right)$ and out 6 (5'. dCCTTTGCACCAAGGAGCTCCGCC- $3^{\prime} \mid$ with amplification conditions: $45 \mathrm{sec}$ at $94^{\circ} \mathrm{C}, 45 \mathrm{sec}$ at $65^{\circ} \mathrm{C}$, and $1.5 \mathrm{~min}$ at $72^{\circ} \mathrm{C}$. One-half microliter of amplification product was used for nested PCR with the $d T p h 1$-specific primer out 1 as described (Souer et al. 1995). Inverse PCR products from the an11-W137 homozygous plant T2141-10 were digested with EcoRI and ligated in M13mp18 vector. Duplicate filters were lifted and hybridized with ${ }^{32} \mathrm{P}$-labeled inverse PCR product obtained from the V2060 family (+ probe) the An11-T2141 revertants (- probe). Differentially hybridizing plaques were picked, classified in cross-hybridization groups, and their inserts hybridized to dot blots containing inverse PCR products isolated from a number of plants segregating for An11-T2141 and an11-W137. Two identical clones R15 and R 24 were identified that are part of the an11 locus.

A corolla V26 cDNA library $(100,000$ PFU $)$ was hybridized with the R24 insert, resulting in fourteen positive plaques. The longest insert was purified, subcloned in pBluescript KS, and sequenced. The $5^{\prime}$-flanking region of the an 11 gene was isolated by inverse PCR. One microgram of V26 genomic DNA was digested with BstYI and ligated overnight in $300 \mu \mathrm{l}$ at $16^{\circ} \mathrm{C}$. For the first round of amplification, $200 \mathrm{ng}$ of ligated DNA was used and the primers: an 11 -fw $\left(5^{\prime}\right.$-dGCTCTAGAATTAAACAACCGGGTC- $\left.3^{\prime}\right)$ and an11-race $\left(5^{\prime}\right.$-dAAGGTACCCACGGCAATGCGGCG $-3^{\prime}$ ). PCR conditions were $1 \mathrm{~min}$ at $94^{\circ} \mathrm{C}, 1 \mathrm{~min}$ at $55^{\circ} \mathrm{C}$, and 2 min at $72^{\circ} \mathrm{C}$ by use of Vent polymerase. Part of this reaction $\{0.5 \mu l)$ was reamplified with the an 11 -fw and anllrace2 primer 15'-dGCGGATCCATGGAGTAAATTGGGTAAG-3'). The PCR products were digested with BamHI and $X \mathrm{BaI}$ and cloned in pBluescript-KS.

Transposon insertion and excision alleles were amplified by PCR with the primers anl l-fw and anll-rev $\left(5^{\prime}\right.$-dCGAATTCTTTAACTTCCCATAAACG-3'), digested with $E c o R I$ and $X b a I$, cloned into pBluescript KS and sequenced.

By use of EST databases available at the NCBI, Arabidopsis and human an11 homologs were identified. The Arabidopsis an11 homolog Atan11- $a$ was identified by the EST sequences R90717 and H35958. The cDNAs, obtained from Dr. T. Newman, were sequenced completely on both strands. A number of
ESTs corresponding to a human an11 homolog were identified. Based on the ESTs W07303 and N78624 primers were designed $\left(5^{\prime}\right.$-CCATAGATCTCAGGCTCG-3' and 5'-TAGGTACCAACACTACACTCTGAG-3') and the cDNA amplified from a liver cDNA library in $\lambda g t 11$ (Clontech). The products were cloned and sequenced.

Nested deletions of cDNA and genomic clones were sequenced by the dideoxy chain termination method with fluorescent M13 primers, employing an Applied Biosystems DNA sequencer model $370 \mathrm{~A}$.

\section{RNA analysis}

RNA isolation and blot analysis were performed according to van Tunen et al. (1988). Transcription run-on assays were performed as described previously by van Blokland et al. (1994).

\section{Expression of AN11 protein in Escherichia coli and antibody production}

The an 11 cDNA fragment between an Ncol site at the in frame ATG codon, Met-28, and a HindIII site following the stop codon was cloned into pRSET B (InVitrogen). This construct was transformed into BL21 (DE3) and cultures were grown at $37^{\circ} \mathrm{C}$ in Luria broth with $50 \mu \mathrm{g} / \mathrm{ml}$ carbenicillin to an $A_{600} \mathrm{~nm}$ of 0.5 . Then isopropylthio- $\beta$-galactoside was added to a final concentration of $1 \mathrm{~mm}$, and cells were grown for an additional $3 \mathrm{hr}$. Induced cells were harvested by centrifugation and resuspended in binding buffer ( $100 \mathrm{mM} \mathrm{NaH}_{2} \mathrm{PO}_{4}, 6 \mathrm{M}$ urea, $10 \mathrm{~mm}$ Tris- $\mathrm{HCl}$ ) at $\mathrm{pH}$ 8.0. After $\mathrm{l} \mathrm{hr}$ at room temperature, the lysate was centrifuged at $10,000 \mathrm{~g}$ for $15 \mathrm{~min}$ to remove debris. Soluble protein was loaded on a Ni-NTA resin column (Qiagen) and washed extensively with binding buffer at $\mathrm{pH}$ 8.0. The column was then washed with binding buffer at $\mathrm{pH} 6.3$ and proteins were eluted with binding buffer at $\mathrm{pH} 4.5$. The presence of the $40-\mathrm{kD}$ AN11 protein in the eluate fraction was confirmed by SDS-PAGE.

For polyclonal antibody generation, AN11 protein was electrophoresed through a $12 \%$ polyacrylamide SDS gel, and electrotransferred to nitrocellulose (Schleicher \& Schuell). The filter was stained with amido black for $1 \mathrm{~min}$ and destained with $10 \%$ acetic acid, 25\% methanol. The AN11 band was cut out, ground to a fine powder, and resuspended in a $0.9 \% \mathrm{NaCl}$ solution. A Swiss female mouse was immunized with approximately $75 \mu \mathrm{g}$ of protein. Two booster injections were given with the same amount of protein every 3 weeks. After an additional 7 days, the serum was collected.

\section{Immunoblot analysis}

Total protein extracts were prepared, and protein concentration determined, as described previously (de Vetten et al. 1992). For subcellular protein fraction, 20 grams of frozen corolla tissue of wild-type R27 and an11- W134 was ground in liquid $\mathrm{N}_{2}$ and the powder was resuspended in $40 \mathrm{ml}$ of ice-cold buffer $(10 \mathrm{~mm}$ Tris- $\mathrm{HCl}$ at $\mathrm{pH} 7.5,1 \mathrm{~mm}$ EDTA, $250 \mathrm{~mm}$ sucrosel. The suspension was passed through a Miracloth filter and was centrifuged for $10 \mathrm{~min}$ at $5,000 \mathrm{~g}$. The pellets of nuclei were further purified on a Percoll gradient as described by van Blokland et al. (1994). The cytosolic fraction was obtained by centrifuging the postnuclei extract for $30 \mathrm{~min}$ at $100,000 \mathrm{~g}$. The pellet obtained after the $100,000 \mathrm{~g}$ centrifugation was designated the microsomal membrane fraction. Identical amounts of cytosolic, microsomal membrane, and nuclear protein $(50 \mu \mathrm{g})$ were electrophoresed on a $12.5 \%$ SDS-polyacrylamide gel. The proteins were transferred to nitrocellulose membranes (Schleicher \& Schuell). Filters were blocked for $2 \mathrm{hr}$ in $1 \% \mathrm{BSA}$ in TBST buffer $(10 \mathrm{~mm}$ Tris- 
$\mathrm{HCl}$ at $\mathrm{pH} 8.0,150 \mathrm{~mm} \mathrm{NaCl}, 0.05 \%$ Tween $20,0.1 \% \mathrm{BSAl}$ and incubated with 1:2000 dilution of mouse anti-AN11 antiserum for $1 \mathrm{hr}$. After three washes with TBST, the filters were incubated with a 1:5000 of goat anti-mouse horseradish peroxidaseconjugated IgG. After washing the filters with TBST, immunodetection was performed with an enhanced chemiluminescence western blotting detection reagent (Amersham).

\section{Plasmid constructions used for transient expression experiments}

The plasmid pANU6 was a gift of Dr. T. Teeri (University of Helsinki, Finland), having the CaMV 35 S promoter fused upstream of the luciferase gene and the nopaline synthase polyadenylation signal. The $d f_{r}-l u c$ vector was constructed by replacing the CaMV promoter with the 1800 -bp petunia dir promoter (Huits et al. 1994). The chsA-GUS construct used was as described by Koes et al. (1990|. The $35 S$-an 11 plasmid was derived from PIP114, which includes the CaMV $35 \mathrm{~S}$ promoter and the 3' sequence of the nopaline synthase gene. The petunia an 11 cDNA was amplified with the primers an11-ATG $15^{\prime}$-dGAGGATCCATGGAAAATTCAAGTCAAGTC-3' $\mid$ and an 1 -trail $\left(5^{\prime}\right.$-dAACAAGAAGCAGCAGGATCC-3' $\mid$ and cloned into the BamHI site of PIP114, resulting in plasmid 35S-an11. The Arabidopsis cDNA of Atan11- $a$ was amplified from the $\lambda$ ZipLox plasmid $172 \mathrm{~B} 4$ by use of the $\mathrm{T} 7$ promoter primer and AtAn $11 \mathrm{Kpn}$ (5'-dTAGGTACCCCTAATACGATAGAAAATG$\left.3^{\prime}\right)$, digested with KpnI and ligated in PIP114 to yield 35S-A. $\tan 11$.

The yeast an 11 homolog, Scan11 was amplified from yeast genomic DNA with the primers Yan01 $15^{\prime}-\mathrm{dAT}$ GAATTCAAATGGATCCCTTTCAC-3' $)$ and Yan02 $\mid 5^{\prime}-\mathrm{dTG}$ TAAGCTTCTCAAAGGACGCGGACG-3') digested with EcoRI and HindIII and cloned into PIP114, resulting in 35SScan11. The human an11 homolog, Hsan11, was amplified from a human liver $\lambda g t 11$ library with the primers HAN $11 B 5$ $\left(5^{\prime}\right.$-CCATAGATCTCAGGCTCG-3' $\mid$ and Human Trail $15^{\prime}$ dTAGGTACCAACACTACACTCTCAG-3' 1 and cloned in the Smal site of PIP114 to yield 35S-Hsan11. For all these PCR amplifications Vent polymerase was used and all constructs were partially sequenced.

\section{Particle bombardment and gene expression assays}

Particle bombardments were performed essentially as previously described (Quattrocchio et al. 1993). After one day incubation at $25^{\circ} \mathrm{C}$, protein extracts were made by grinding the corolla in $400 \mu 150 \mathrm{~mm} \mathrm{NaPi}$ at pH 7.0, 2 mM EDTA, $20 \mathrm{~mm}$ DTT and $4 \%$ PVP. Luciferase activity was measured with the Luciferase Assay System (Promega Corp., WI), and GUS activity was measured as described (Koes et al. 1990). Data are expressed as the ratio of arbitrary light units to arbitrary units of fluorescence.

\section{Acknowledgments}

We thank Dr. E. Grotewold for critical comments on the manuscript. We thank Drs. L. Britsch and G. Angenent for the kind gift of anti-F3H and anti-FBPl antiserum, Drs. H. van Luenen, M. Haring, and A. Schinkel for providing DNA samples, Drs. T. Teeri and T. Newman for providing plasmids, and $M$. de Haas and Dr. P. Borst for providing a liver cDNA library. Thanks are also due to P. Hoogeveen and M. Meesters for their care of the plants. N.dV. is supported by a grant from the EU-BIOTECH Research program (grant BIO2 CT93 0101), F.Q. is supported by the Nederlands Organization for Chemical Research (SON).
The publication costs of this article were defrayed in part by payment of page charges. This article must therefore be hereby marked "advertisement" in accordance with 18 USC section 1734 solely to indicate this fact.

\section{Note added in proof}

The sequence data described in this paper have been submitted to GenBank under accession nos. U94748 (an11), U94747 |Hsan11), and U94746 (Atan11-a).

\section{References}

Beld, M., C. Martin, H. Huits, A.R. Stuitje, and A.G.M. Gerats. 1989. Flavonoid synthesis in Petunia hybrida: Partial char acterization of dihydroflavonol 4-reductase genes. Plant Mol. Biol. 13: 491-502.

Bowler, C., G. Neuhaus, H. Yamagata, and N.H. Chua. 1994a. Cyclic GMP and calcium mediate phytochrome phototransduction. Cell 77: 73-82.

_- 1994b. Phytochrome signal transduction pathways are regulated by reciprocal control mechanisms. Genes \& Dev. 8: 2188-2202.

Britsch, L., B. Ruhnau-Brich, and G. Forkmann. 1991. Molecular cloning, sequence analysis and in vitro expression of flavanone $3 \beta$-hydroxylase from Petunia hybrida. 1 . Biol. Chem. 267: 5380-5387.

Cañas, L.A., M. Busscher, A. Angenent, J.P. Beltran, and A.J. van Tunen. 1994. Nuclear localization of the petunia MADS box protein FBP1. Plant J. 6: 597-604.

Clark, M.A., L.E. Özgür, T.M. Conway, J. Dispoto, S.T. Crooke, and J.S. Bomalaski. 1991. Cloning of a phospholipase A2activating protein. Proc. Natl. Acad. Sci. 88: 5418-5422.

Cone, K.C., S.M. Cocciolone, F.A. Burr, and B. Burr. 1993. Maize anthocyanin regulatory gene $p 1$ is a duplicate of $c 1$ that functions in the plant. Plant Cell 5: 1795-1805.

Consonni, G., F. Geuna, G. Gavazzi, and C. Tonelli. 1993. Molecular homology among members of the $R$ gene family from maize. Plant I. 3: 335-346.

de Vetten, N.C., G. Lu, and R.J. Ferl. 1992. A maize protein associated with the G-box binding complex has homology to brain regulatory proteins. Plant Cell 4: 1295-1307.

Dellaporta, S.J., J. Wood, and J.B. Hicks. 1983. A plant DNA minipreperation, version II. Plant Mol. Biol. Rep. 1: 19-21.

Doodeman, M., A.G.M. Gerats, A.W. Schram, P. de Vlaming, and F. Bianchi. 1984. Genetic analysis of instability in Petunia hybrida 2 . Unstable mutations at different loci as the result of transpositions of the genetic element inserted at the An1 locus. Theor. Appl. Genet. 67: 357-366.

Dooner, H.K., T. Robbins, and R. Jorgensen. 1991. Genetic and developmental control of anthocyanin biosynthesis. Annu. Rev. Genet. 25: 173-199.

Fong, H.K.W., J.B. Hurley, S. Hopkins, R. Miake-Lye, M.S. Johnson, R.F. Doolittle, and M.I. Simon. 1986. Repetitive segmental structure of the transducin $\beta$ subunit: Homology with the $C D C 4$ gene and identification of related mRNAs. Proc. Natl. Acad. Sci. 83: 2162-2166.

Garritsen, A., P.J.M. Galen, and W.F. Simonds. 1993. The Nterminal coiled-coil domain of $\beta$ is essential for association: a model for G-protein $\beta$ subunit interaction. Proc. Natl. Acad. Sci. 90: 7706-7710.

Gerats, A.G.M., H. Huits, E. Vrijlandt, C. Maraña, E. Souer, and M. Beld. 1990. Molecular characterization of a nonautonomous transposable element $(d T p h 1)$ of petunia. Plant Cell 2: 1121-1128. 
Goodrich, J., R. Carpenter, and E.S. Coen. 1992. A common gene regulates pigmentation pattern in diverse plant species. Cell 68: $955-964$.

Hattori, T., V. Vasil, L. Rosenkrans, L.C. Hannah, D.R. McCarty, and I.K. Vasil. 1992. The Viviparous-1 gene and abscisic acid activate the $C 1$ regulatory gene for anthocyanin biosynthesis during seed maturation in maize. Genes \& Dev. 6: 609-618.

Huits, H.S.M., A.G.M. Gerats, M.M. Kreike, J.N.M. Mol, and R.E. Koes. 1994. Genetic control of dihydroflavonol 4- reductase gene expression in Petunia hybrida. Plant I. 6: 295-310.

Joshi, C.P. 1987. An inspection of the domain between putative TATA-box and translation start site in 79 plant genes. Nucl. Acids Res. 15: 6643-6653.

Kamibayashi, C., R.L. Lickteig, R. Esters, G. Walter, and M.C. Mumby. 1992. Expression of the A subunit of protein phosphatase $2 \mathrm{~A}$ and characterization of its interactions with the catalytic and regulatory subunits. J. Biol. Chem. 267: 2186421872.

Koes, R.E., R. Van Blokland, F. Quattrocchio, A.J. Van Tunen, and J.N.M. Mol. 1990. Chalcone synthase promoters in petunia are active in pigmented and unpigmented cell types. plant Cell 2: 379-392.

Koes, R.E., F. Quattrocchio, and J.N.M. Mol. 1994. The flavonoid biosynthetic pathway in plants: Function and evolution. BioEssays 16: 123-132.

Komachi, K., M.J. Redd, and A.D. Johnson. 1994. The WD repeats of Tupl interact with the homeodomain protein alpha2. Genes \& Dev. 8: 2857-2867.

Lamour, L., Y. Lécluse, C. Desmaze, M. Spector, M. Bodescot, A. Aurias, M. Osley, and M. Lipinski. 1995. A human homolog of the S. cerevisiae HIR1 and HIR2 transcriptional repressors cloned from the DiGeorge syndrome critical region. Hum. Mol. Genet. 4: 791-799.

Lloyd, A.M., V. Walbot, and R.W. Davis. 1992. Arabidopsis and Nicotiana anthocyanin production activated by maize regulators $R$ and C1. Science 258: 1773-1775.

Ludwig, S.R. and S.R. Wessler. 1990. Maize R Gene Family: Tissue specific helix-loop-helix proteins. Cell 62: 849-851.

Lüscher, B., E. Christenson, D.W. Litchfield, E.G. Krebs, and R.N. Eisenman. 1990. Myb DNA binding inhibited by phosphorylation at a site deleted during oncogenic activation. Nature 344: 517-522.

Marzioch, M., R. Erdman, M. Veenhuis, and W.-H. Kunau. 1994. PAS7 encodes a novel yeast member of the WD-40 repeat protein family essential for import of 3-oxoacyl-CoA thiolase, a PTS2- containing protein, into peroxisomes. EMBO $J$. 13: 4908-4918.

Mayer, R.E., P. Hendrix, P. Cron, R. Matthiers, S.R. Stone, J. Goris, W. Merlevede, J. Hofstternge, and B.A. Hemmings. 1991. Structure of the $55-\mathrm{kDa}$ regulatory subunit of protein phosphatase 2A: Evidence for a neuronal-specific isoform. Biochemistry 30: 3589-3597.

McCarty, D.R., T. Hattori, C.B. Carson, V. Vasil, M. Lazar, and I.K. Vasil. 1991. The viviparous-1 developmental gene of maize encodes a novel transcriptional activator. Cell 66: 895-905.

Mol, J., G. Jenkins, E. Schäfer, and D. Weiss. 1996. Signal perception, transduction, and gene expression involved in anthocyanin biosynthesis. Crit. Rev. Plant Sci. 15: 525-557.

Moyano, E., J.F. Martínez-Garcia, and C. Martin. 1996. Apparent redundancy in $m y b$ gene function provides gearing for the control of flavonoid biosynthesis in Antirrhinum flowers. Plant Cell 8: 1519-1532.

Neer, E.J. and D.E. Clapham. 1988. Roles of G protein subunits in transmembrane signaling. Nature 333: 129-134.
Neer, E.J., C.J. Schmidt, R. Nambudripad, and T.F. Smith. 1994. The ancient regulatory-protein family of WD-repeat proteins. Nature 371: 297-300.

Neuhaus, G., C. Bowler, R. Kern, and N.-H. Chua. 1993. Calcium/calmodulin dependent and independent phytochrome signal transduction pathways. Cell 73: 937-952.

Paz-Ares, J., D. Ghosal, U. Wienand, P.A. Peterson, and H. Saedler. 1987. The regulatory C1 locus of Zea mays encodes a protein with homology to myb proto-oncogene products and with structural similarities to transcriptional activators. EMBO I. 6: 3553-3558.

Quattrocchio, F. 1994. "Regulatory genes controlling flower pigmentation in Petunia hybrida." Ph.D. thesis, Vrije Universiteit, Amsterdam, The Netherlands.

Quattrocchio, F., J.F. Wing, H.T.C. Leppen, J.N.M. Mol, and R.E. Koes. 1993. Regulatory genes controlling anthocyanin pigmentation are functionally conserved among plant species and have distinct sets of target genes. Plant Cell 5: 1497-1512.

Ron, D., C.-H. Chen, J. Caldwell, L. Jamieson, E. Orr, and D. Mochly-Rosen. 1994. Cloning of an intracellular receptor for protein kinase $C$ : A homolog of the $\beta$ subunit of $G$ proteins. Proc. Natl. Acad. Sci. 91: 839-843.

Schmid, J., P.W. Doerner, S.D. Clouse, R.A. Dixon, and C.J. Lamb. 1990. Developmental and environmental regulation of a bean chalcone synthase promoter in transgenic tobacco. plant Cell 2: 619-631.

Shirley, B.W. 1996. Flavonoid biosynthesis: "New" functions for an "old" pathway. Trends Plant Sci. 1: 363-402.

Souer, E., F. Quattrocchio, N. de Vetten, J.N.M. Mol, and R.E. Koes. 1995. A general method to isolate genes tagged by a high copy number transposable element. Plant 1. 7: 677-685.

Souer, E., A. van Houwelingen, D. Kloos, J.N.M. Mol, and R.E. Koes. 1996. The no apical meristem gene of petunia is required for pattern formation in embryos and flowers and is expressed at meristem and primordia boundaries. Cell 85: $159-170$.

Stafford, H.A. 1991. Flavonoid evolution: An enzymic approach. Plant Physiol. 96: 680-685.

van Blokland, R., N. van der Geest, J.N.M. Mol, and J.M. Kooter. 1994. Transgene-mediated suppression of chalcone synthase expression in Petunia hybrida results from an incresase in RNA turn-over. Plant J. 6: 861-877.

van Tunen, A.J., R.E. Koes, C.E. Spelt, A.R. Van der Krol, A.R. Stuitje, and J.N.M. Mol. 1988. Cloning of the two chalcone flavanone isomerase genes from Petunia hybrida: Coordinate, light-regulated and differential expression of flavonoid genes. EMBO I. 7: 1257-1263. 


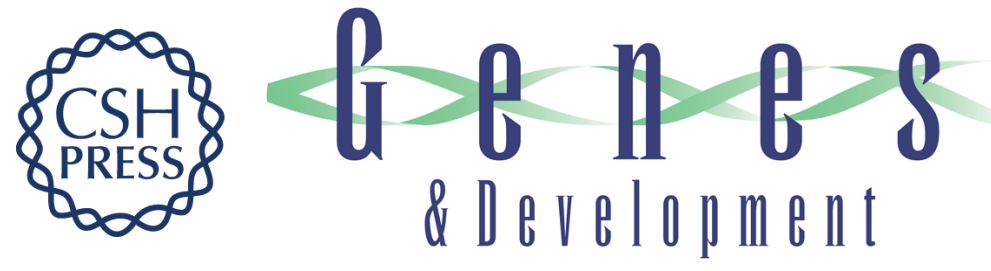

\section{The an11 locus controlling flower pigmentation in petunia encodes a novel WD-repeat protein conserved in yeast, plants, and animals.}

$\mathrm{N}$ de Vetten, F Quattrocchio, J Mol, et al.

Genes Dev. 1997, 11:

Access the most recent version at doi:10.1101/gad.11.11.1422

References This article cites 45 articles, 17 of which can be accessed free at:

http://genesdev.cshlp.org/content/11/11/1422.full.html\#ref-list-1

License

Email Alerting

Service

Receive free email alerts when new articles cite this article - sign up in the box at the top right corner of the article or click here.

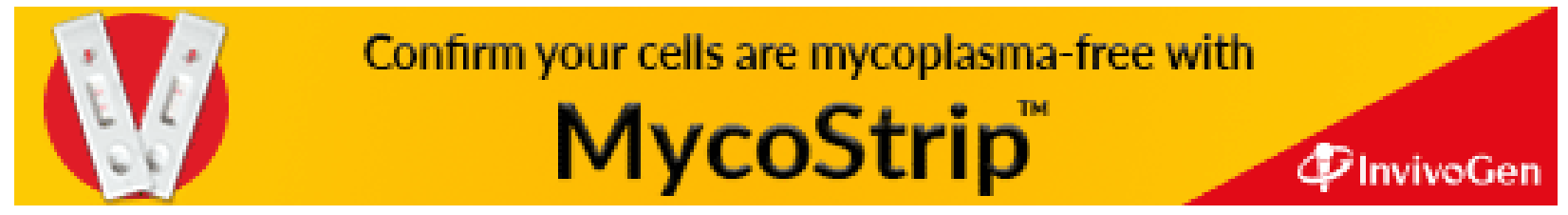

